\title{
Phosphorus, nitrogen and sediment losses from irrigated cropland and pasture grazed by cattle and sheep
}

\author{
R.W. MCDOWELL and D.J. HOULBROOKE \\ AgResearch Ltd, Invermay Agricultural Centre, Private Bag 50034, Mosgiel, New Zealand \\ richard.mcdowell@agresearch.co.nz
}

\begin{abstract}
Grazing forage crops during winter can lead to soil physical damage and contaminant losses especially on Pallic soils prone to compaction and structural degradation. A site in North Otago (Timaru silt loam) with 2 years sheep and cattle grazing on winter forage crops and pasture was used to measure phosphorus $(\mathrm{P})$ and nitrogen $(\mathrm{N})$ losses in sub-surface (leachate from shallow lysimeters) flow and P losses in overland flow. Overland flow losses of P were c. $0.95 \mathrm{~kg} \mathrm{P} / \mathrm{ha} / \mathrm{yr}$ from cattle-grazed winter forage crop plots compared to 0.5 $\mathrm{kg} \mathrm{P} / \mathrm{ha} / \mathrm{yr}$ from sheep-grazed winter forage crops. Approximately $30 \%$ of the $\mathrm{P}$ losses occurred in response to irrigation events. In sheep grazed pasture plots 0.15 $\mathrm{kg} \mathrm{P} / \mathrm{ha} / \mathrm{yr}$ was lost of which $<20 \%$ was attributable to irrigation events. Subsurface loss of $\mathrm{P}$ was greatest from sheep grazed pasture $(0.084 \mathrm{~kg} \mathrm{P} / \mathrm{ha} / \mathrm{yr})$ than from sheep crop land $(0.038 \mathrm{~kg} \mathrm{P} / \mathrm{ha} / \mathrm{yr})$ and cattle crop land $(0.067$ $\mathrm{kg} \mathrm{P} / \mathrm{ha} / \mathrm{yr}$ ). The relative loss of nitrate-N was significantly greater from cattle-grazed crop plots than from sheep-grazed crop plots and for urine patch areas compared with non-urine patch areas. Mitigation of $\mathrm{N}$ and $\mathrm{P}$ losses in grazed winter forage crops should focus on minimising irrigation-induced overland flow and strategies like restricting grazing to 4 hours for maintenance feed and the use of a stand-off pad at other times.
\end{abstract}

Keywords: phosphorus, nitrogen, sediment, irrigation, overland flow, treading, grazing, pasture, crop land

\section{Introduction}

The loss of nutrients (nitrogen $(\mathrm{N})$ and phosphorus $(\mathrm{P})$ ) and suspended sediment (SS) from land to surface waters is associated with impaired water quality (Nash \& Halliwell 1999; Wilcock et al. 2007). Winter-grazed forage crop systems are quite different to rotationallygrazed pasture systems since forage crops are only grazed once (or sometimes twice) a year. Grazing also occurs at a very high stocking density at a time when soil moisture is typically close to or at field capacity (Drewry \& Paton 2005). These conditions are likely to promote $\mathrm{N}$ and $\mathrm{P}$ losses. Indeed, simulation modelling of winter forage crops in the Bog Burn catchment (Southland) suggests that $\mathrm{N}$ loss (largely nitrate-N) would be c. $55 \mathrm{~kg} / \mathrm{yr}$ (Monaghan et al. 2007). Furthermore, winter grazing of forage crops has been shown in previous work to cause a decline in soil physical quality measurements like infiltration rate and compaction (Bilotta et al. 2007; Drewry \& Paton 2005; Houlbrooke et al. 2006). This results in increased overland flow and loss of SS and P (McDowell et al. 2003, 2005). The loss of P to New Zealand freshwaters is important since eutrophication in $87 \%$ of sites tested from 1996 to 2006 by regional councils was controlled by P inputs (McDowell \& Larned 2008).

While some work has established that nutrient losses increase under cattle-grazed winter forage cropping (e.g. McDowell 2006a), many questions still remain. For instance, while the potential for overland flow may increase, the volume of drainage decreases; does this also cause a decrease in nutrient loss by sub-surface flow? Furthermore, what is the effect of irrigation on nutrient and sediment losses from grazed winter forage crops? In addition, no work has compared nutrient and sediment losses from cattle- and sheep-grazed winter forage crops. To address these questions, a trial was established in the North Otago rolling downlands. The site had a history of sheep and cattle grazing winter forage crops (Brassica sp.) for 2 years on irrigated plots. This paper reports on nutrient ( $\mathrm{N}$ and $\mathrm{P}$ ) and sediment losses in overland flow and nutrient losses in sub-surface flow from cattle- and sheep-grazed irrigated winter forage crops and irrigated pasture grazed by sheep.

\section{Materials and Methods \\ Site details, treatments and sampling}

The research site was located on a Timaru silt loam soil, typical of the area, and is classified as a Mottled Fragic Pallic soil (Hewitt 1998). The research site was established in autumn 2004 as part of a larger trial analysing the impact of land use change on soil quality and forage production. The 2007 winter forage crop was triticale, preceded in the two previous winters by swede (2006) and kale (2005). The trial site contains 32 plots, approximately $10 \mathrm{~m}$ wide and $25 \mathrm{~m}$ long running down the slope. There were four replicates of eight treatments with permutations of: Irrigated or Dryland, Sheep or Cattle, and Pasture or Winter Forage Crop. This paper reports on measurements taken in three treatments: irrigated crop land grazed by sheep or cattle and irrigated pasture grazed by sheep. The plots received maintenance fertiliser requirements of $50 \mathrm{~kg} \mathrm{P} / \mathrm{ha} / \mathrm{yr}, 70 \mathrm{~kg} \mathrm{~S} / \mathrm{ha} / \mathrm{yr}$ 
and $75 \mathrm{~kg} \mathrm{~N} / \mathrm{ha} / \mathrm{yr}$.

The winter forage crop plots were established in early summer 2006/2007 and grazed for 24 hours in autumn 2007 (16 May) and then for a further 24 hours on the 27 July at stocking densities of either 200 cattle or 2500 lambs/ha. Grazing of the pasture plots was scheduled according to pasture growth (supplemented by irrigation) every 15 to 30 days at a mean stocking rate of 950 sheep/ ha/d. Approximately $35 \mathrm{~mm}$ of irrigation water was applied to half of the plots using fixed K-Line pods. These irrigation events were scheduled when soil moisture levels fell between 50 and $66 \%$ of available water capacity, as determined by an aquaflex ${ }^{\mathrm{TM}}$ soil moisture tape buried at $5-20 \mathrm{~cm}$ depth in one of the plots. There was $464 \mathrm{~mm}$ of rainfall from March 2007 to April 2008. Median rainfall for the North Otago region is approximately $500 \mathrm{~mm}$. During the year of measurement, $525 \mathrm{~mm}$ of water was applied to pasture plots, split evenly over 15 irrigations, and $206 \mathrm{~mm}$ was applied to cropped plots over nine irrigations.

In each of the treatment plots, a sub-plot was installed consisting of four 2-m length wooden boards $(150 \mathrm{~mm}$ wide by $25 \mathrm{~mm}$ thick), dug into the ground to $125 \mathrm{~mm}$ depth, to form a diamond shape. An open-ended tray was located at the down-slope corner and was used to gather all overland flow from each rainfall event into a container placed below the height of the tray and connected via a hose.

In addition to sub-plots, three lysimeters were excavated per main treatment plot in March 2007 to measure potential sub-surface flow via interflow within the A-horizon toward the toe of the slope. Small lysimeters were collected (15 cm diameter, $24 \mathrm{~cm}$ depth) down to the inter-grade between the A and $\mathrm{B}$ horizon. It is acknowledged that this approach may estimate greater loads of $\mathrm{N}$ leached compared to that expected from larger lysimeters incorporating subsoil and with less edge-flow effects. However, this approach is likely to better represent flow pathways in situations where subsoil is effectively impermeable causing water to flow downslope only through topsoil. Lysimeters were collected by placing the casing on the soil surface, digging around it and pushing down in steps while avoiding disturbance to the inside soil structure. The lysimeters were protected from edge flow effects by inserting a coating of petrolatum between the soil monolith and lysimeter casing.

The lysimeters were housed in a dedicated outdoor facility at the Invermay Agricultural Centre. Lysimeters were treated the same as at the North Otago site, including simulated animal grazing, fertiliser timing and application rate, weed control plus rainfall and irrigation volumes. Half of the lysimeters received urine at rates equivalent to $10 \mathrm{~L} / \mathrm{m}^{2}(0.18 \mathrm{~L} /$ lysimeter $)$ and $3.95 \mathrm{~L} / \mathrm{m}^{2}(0.07 \mathrm{~L} /$ lysimeter) for cows and sheep, respectively (Haynes \&
Williams 1993; de Klein et al. 2003). The concentration of $\mathrm{N}$ in the artificial urine was $6 \mathrm{~g} \mathrm{~N} / \mathrm{L}$ for both cattle and sheep, with the change in urine volume providing the difference in $\mathrm{N}$ urine loading of $580 \mathrm{~kg} \mathrm{~N} / \mathrm{ha}$ for cattle and $229 \mathrm{~kg} \mathrm{~N} / \mathrm{ha}$ for sheep (Smith et al. 2005; Haynes \& Williams 1993; de Klein et al. 2003). The artificial urine was made in accordance with Smith et al. (2005).

Samples were taken from overland flow sub-plots and lysimeters in response to flow events between March 2007 and April 2008. Samples of sub-surface flow were collected under suction to prevent anaerobic conditions in the lysimeters.

\section{Measurements}

Unpublished 2007 data for soil bulk density and macroporosity (percentage of soil pores $>30 \mathrm{im}$ ) for the $0-5 \mathrm{~cm}$ depth were measured in accordance with methodology described and reported for 2005 and 2006 data in Houlbrooke et al. (2006). Additional saturated hydraulic conductivity $\left(K_{\text {sat }}\right)$ samples were measured in September 2007 (after grazing) at the $0-5 \mathrm{~cm}$ depth from three paired samples per plot as per Drewry et al. (2000).

Samples of overland flow and leachate were filtered through a $0.45 \mu \mathrm{m}$ membrane and analysed for dissolved reactive $\mathrm{P}$ (DRP) and total dissolved reactive $\mathrm{P}$ (TDP) after persulphate digestion. Persulphate digestion also occurred on unfiltered samples of overland flow to determine total P (TP) and total N (TN). Since little particulate material is commonly measured in leachate from lysimeters such as those used here, TDP was measured instead of TP (McDowell \& Monaghan 2002). For N, only nitrate-N was measured in leachate. Fractions defined as dissolved unreactive (largely organic) P (DOP) and particulate $\mathrm{P}(\mathrm{PP})$ were determined as the difference between TDP and DRP and TP less TDP, respectively. All $\mathrm{P}$ analyses used the colorimetric technique of Watanabe \& Olsen (1965). Suspended sediment was determined by weighing the residue left after filtration through a Whatman GF/A glass fibre filter paper (c. 1.2 $\mu \mathrm{m}$ pore size).

Nutrient losses have been calculated using the product of nutrient concentration and volume of overland flow or leachate collected. Relative percentage loss of $\mathrm{N}$ was determined at a plot scale $\left(250 \mathrm{~m}^{2}\right)$ by weighting the proportion of urine and non urine patch areas from both sheep and cattle treatments. Urine patch coverage area was determined from Haynes \& Williams (1993) for two grazing events using mean data for the number and area of urinations for both sheep and cattle.

Point-wise data for each sample and summary data (mean concentrations, soil physical parameters and total loads) for the whole sampling period were analysed by ANOVA, fitting terms for the factorial interaction of stock type (land use) and urine application. Where used, the 
least significant difference at $\mathrm{P}<0.05$ is presented between treatments (e.g. land use and grazing (i.e. urine for $\mathrm{N}$ losses), and interactions (e.g. land use and grazing). All denoted differences are at the $\mathrm{P}<0.05$ level of significance. Values for $K_{\text {sat }}$ were log-transformed before analysis.

\section{Results and Discussion}

\section{Soil physical conditions and hydrology}

From the end of February 2007, to the beginning of March 2008, 21 overland flow events were recorded. Irrigation during October - April caused eight of these, while rainfall caused events during winter and on one occasion during the irrigation season. Seven of the overland flow events occurred prior to the July grazing. Drainage events followed a similar pattern. On average, cropped plots generated a total of $35 \mathrm{~mm}$ of overland flow and $140 \mathrm{~mm}$ of sub-surface flow (leachate). The pasture plots generated significantly less overland flow $(13 \mathrm{~mm})$, but similar sub-surface flow $(120 \mathrm{~mm})$ per event. Significantly more overland flow was produced from the cattle $(45 \mathrm{~mm})$ than sheep $(25 \mathrm{~mm})$ grazed winter forage crop plots. Differences in overland flow may be attributable to the decreased macroporosity in the cattle $(6.4 \% \mathrm{v} / \mathrm{v})$ compared to sheep $(11.3 \% \mathrm{v} / \mathrm{v})$ grazed plots (McDowell et al. 2003). However, the lack of difference in sub-surface flow suggests that infiltration was not restricting water flow and that overland flow was probably via saturation-excess conditions. Indeed there was no significant difference in $K_{\text {sat }}$ between cattle $(70 \mathrm{~mm} / \mathrm{h})$ or sheep $(75 \mathrm{~mm} / \mathrm{h})$ grazed plots.

\section{Sub-surface flow}

Losses of $\mathrm{P}$ fractions and nitrate-N in sub-surface flow are given in Tables 1 and 2. Due to variability in urine deposition, using lysimeter data to make inferences at other scales is tenuous. Hence, loads are presented relative to the greatest load (Table 1). With time, the concentration of $\mathrm{NO}_{3}^{-}-\mathrm{N}$ in sub-surface flow from lysimeters with urine applied was greater than from those without urine applied (Fig. 1). The $\mathrm{NO}_{3}^{-}-\mathrm{N}$ concentration was significantly greater from lysimeters with cattle urine applied than those with sheep urine applied. The application of urine (grazing simulation) in mid-May enriched $\mathrm{NO}_{3}{ }^{-}-\mathrm{N}$ concentrations in late June. However, the second application in late July was leached by two drainage events within 10 days of application. Nitrate-N concentrations remained enriched throughout the spring fallow period.

Comparing the relative loads of $\mathrm{NO}_{3}^{-}-\mathrm{N}$ lost in leachate indicated there was a significant land use (cattle versus sheep) effect, grazing effect, and land use-grazing interaction. The land use-grazing interaction occurred because $\mathrm{NO}_{3}^{-}-\mathrm{N}$ loss from cattle urine patches was significantly greater than from sheep urine patches.
Table 1 Relative loss of $\mathrm{NO}_{3}^{-}-\mathrm{N}$ in sub-surface flow from mini-lysimeters taken from cattle- and sheep-grazed winter forage crop plots (with or without urine applied). $\mathrm{LSD}_{05}$ is the least significant difference at the $\mathrm{P}<0.05$ level of significance.

\begin{tabular}{llc}
\hline Urine & Cattle & Sheep \\
\hline Yes & $100 \%$ & $100 \%$ \\
No & $8.8 \%$ & $40.6 \%$ \\
LSD $_{05}$ & 19.8 & 48.3 \\
\hline
\end{tabular}

Table 2 Mean load (kg P/ha/yr) of $\mathrm{P}$ fractions (dissolved reactive $P$, DRP; dissolved organic P; total dissolved P, TDP) lost in subsurface flow from mini-lysimeters taken from cattle- and sheep-grazed winter crops and sheep-grazed pasture plots. LSD $_{05}$ is the least significant difference at the $\mathrm{P}<0.05$ level of significance.

\begin{tabular}{lccc}
\hline Land use & DRP & DOP & TDP \\
\hline Cattle - cropland & 0.024 & 0.043 & 0.067 \\
Sheep - cropland & 0.010 & 0.028 & 0.038 \\
Sheep - pasture & 0.043 & 0.041 & 0.084 \\
LSD $_{05}$ & 0.041 & 0.024 & 0.060 \\
\hline
\end{tabular}

However, for no-urine patches, there was no significant difference in $\mathrm{NO}_{3}^{-}-\mathrm{N}$ loss under sheep or under cattle grazing. The enhanced loss of $\mathrm{NO}_{3}^{-}-\mathrm{N}$ from urine patches compared to no-urine areas and cattle grazing versus sheep grazing was expected and has been reported extensively elsewhere. However, our data suggest that animals are the predominant driver for $\mathrm{NO}_{3}^{-}-\mathrm{N}$ loss from grazed winter forage crops and that abating animal urine effects will have the greatest mitigation of $\mathrm{N}$ loss in this system. One strategy to mitigate nitrate- $\mathrm{N}$ is the application of nitrification inhibitors. This is being evaluated at this site, but not reported here as the data set is not complete.

Assuming that urine patch coverage from two crop grazing events was approximately $8 \%$ of plot area under cattle grazing and $15 \%$ under sheep grazing (Haynes \& Williams 1993), sheep $\mathrm{NO}_{3}^{-}-\mathrm{N}$ losses were $85 \%$ of cattle losses. The greater coverage area under sheep reflects the greater animal density and frequency of urinations, but small urine volume and patch coverage area. Sheep are capable of dispersing urine more uniformly than cattle (Haynes \& Williams 1993).

Preliminary work indicated that little sediment was lost in sub-surface flow; these data are not presented. P losses in sub-surface flow are given in Table 2. No significant differences were noted for any of the $\mathrm{P}$ fractions with stock type or land use. The reason for this probably lies with the interaction of $\mathrm{P}$ in drainage water and soil. Unless bypass flow occurs, P loss in subsurface flow usually reflects topsoil $\mathrm{P}$ concentration (McDowell \& Sharpley 2001). Olsen P concentration in 
Figure 1 Mean $\mathrm{NO}_{3}-\mathrm{N}$ concentrations in leachate collected from lysimeters of each treatment. Black symbols signify cattle treatment and grey signifies sheep. A solid line signifies urine patch and a dashed line signifies no urine treatment. Arrows indicate grazing events.

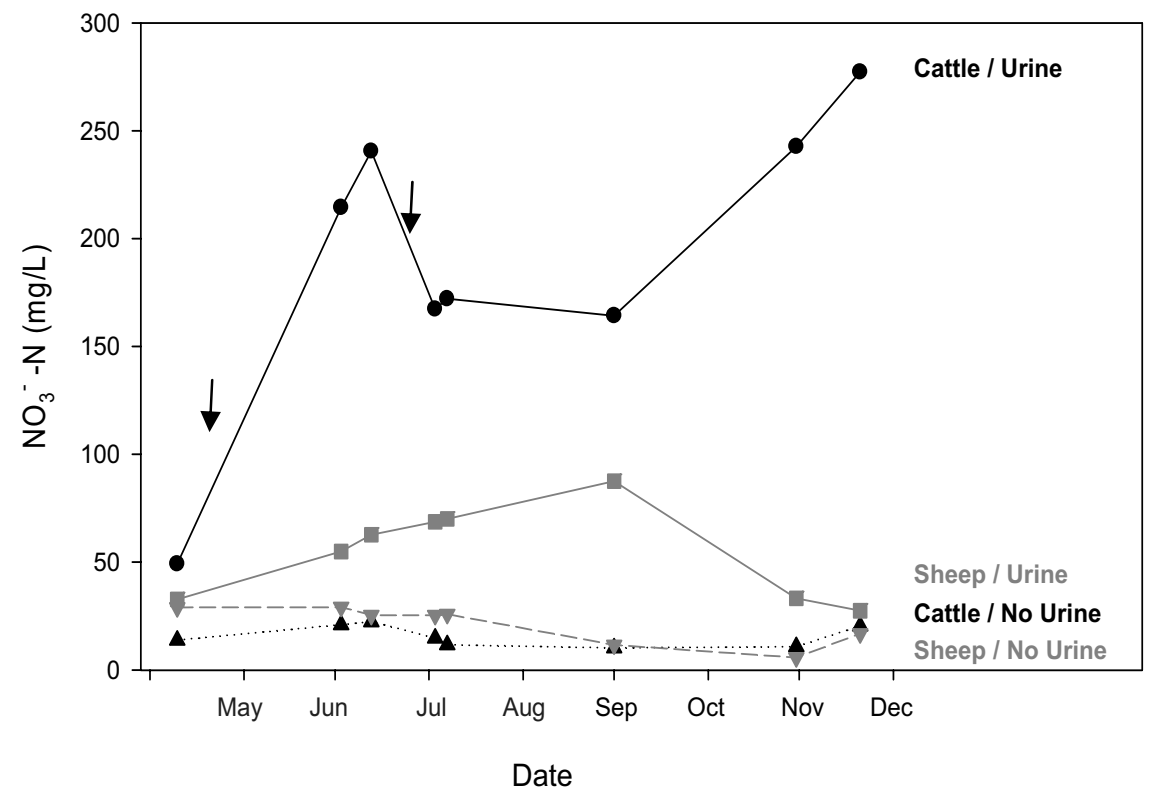

Figure 2 Mean $( \pm 95 \%$ confidence intervals) loads of dissolved reactive $P(D R P)$, total $P$, and suspended sediment in $\mathrm{kg}$ or $\mathrm{Mg} / \mathrm{ha} / \mathrm{y}$ for sheep grazed pasture plots and plots with cattle and sheep grazing winter forage crops. The contribution of loss via irrigation events is noted by hatching within each bar.

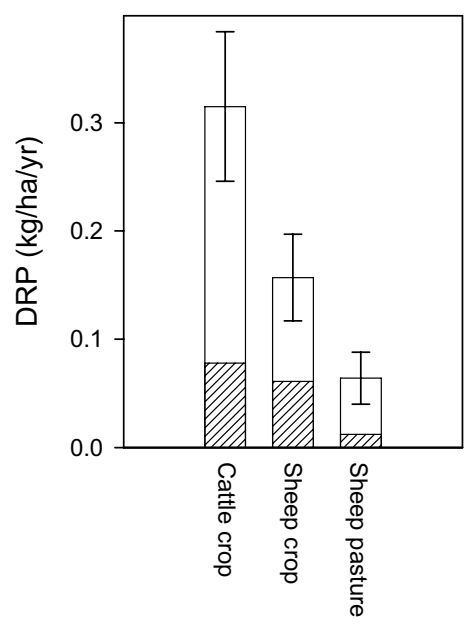

the top $7.5 \mathrm{~cm}$ of soil was not significantly different between stock type or land use (average of $28 \mathrm{mg} / \mathrm{kg}$ and range of between 24 and $32 \mathrm{mg} / \mathrm{kg}$ ).

In general, more $\mathrm{P}$ was lost as DOP than as DRP. The former is comprised of largely organic P forms, while DRP is mostly orthophosphate. Many organic P compounds are less well sorbed to soil than orthophosphate, meaning that they are preferentially lost compared to orthophosphate in sub-surface flow (Leytem et al. 2002). The dominance of DOP over DRP loss can

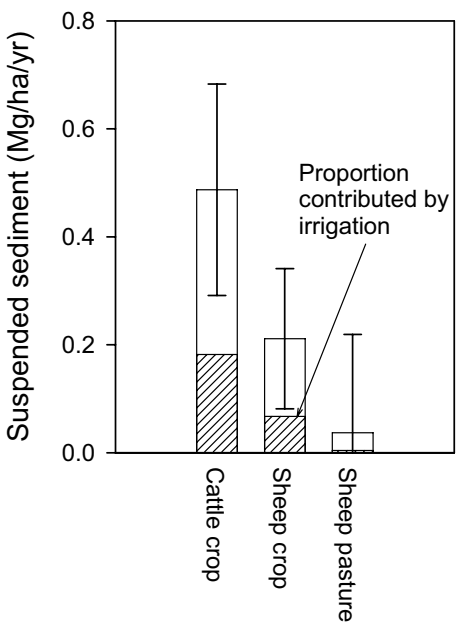

be emphasised in cropped systems where more sorption sites are available via cultivation compared to pasture soils with well established, and possibly less sorptive, drainage pores (Thomas et al. 1997).

\section{Overland flow}

In general, overland flow was the main mechanism for $\mathrm{P}$ and sediment loss. Phosphorus losses in sub-surface flow made up about $6 \%$ of total (overland and sub-surface) loss. Preliminary data indicated that the picture was more 
extreme for sediment ( $<1 \%$ sub-surface); hence, analysis of SS in sub-surface flow was quickly stopped. Conversely, the majority of $\mathrm{N}$ losses occurred via subsurface rather than overland routes, resulting in only data for $\mathrm{N}$ loss in sub-surface flow being presented.

Loads for $\mathrm{P}$ and sediment losses are given in Figure 2. Loads are presented due to the effect of scale. Unlike N, $\mathrm{P}$ and sediment concentrations usually change en-route from paddock to stream, meaning that scaling-up plot scale data can be erroneous due to processes like deposition and sorption (McDowell et al. 2004), but treatment comparisons are valid. There was a significant difference between land uses and between stock types and for the interaction between stock type and land use such that P (all fractions) and SS losses decreased in order from cattle crop $>$ sheep crop $>$ sheep pasture. In general, P losses from the cattle-grazed crop plots were double that of the sheep-grazed plots and seven times that of the sheep-grazed pasture. The difference in stock type on cropped land can be partly attributed to greater overland flow volumes. However, an additional effect is the greater potential loss of $\mathrm{P}$ from excreta (largely dung) by cattle compared to sheep stocked at the same rate (McDowell 2006b). On the other hand, SS loss probably reflects animal disturbance of the soil surface. Several studies have noted the increased loss of sediment from cattle- compared to sheep-grazed pastures and indeed stocking rate or treading damage (e.g. Nguyen et al. 1998; McDowell et al. 2003). However, this study is the first to examine losses under the same management and environmental conditions.

Compared to the cropped plots, $\mathrm{P}$ and sediment losses from pasture were much less. This is due mostly to less soil disturbance by animal traffic, and the filtration of particles in overland flow by grasses. This can be seen by the greater proportion of $\mathrm{P}$ lost in dissolved forms (TDP $=56 \%$ ) compared to the cropped plots grazed by sheep (TDP $=37 \%)$.

The load of P lost in the cattle-grazed crop plots was less than that reported in other studies. For example, McDowell (2006a) reported a loss of $1.9 \mathrm{~kg} \mathrm{P} / \mathrm{ha} / \mathrm{yr}$ from winter forage crops grazed by dairy heifers in South Otago. The main difference (both were on similar slopes and soils) is the drier climate in North Otago. To overcome moisture deficits during and after germination, irrigation was used $(206 \mathrm{~mm})$. However, the effect of animal treading and winter forage cropping is commonly overlooked. Using the same irrigation volume for winter forage crops as for pasture can lead to over-watering and overland flow, especially when soil infiltration rates are decreased due to treading and compaction. Hence, it was not surprising to see that about $30 \%$ of $\mathrm{P}$ losses and 32 $37 \%$ of SS losses from the cropped plots occurred during irrigation (Fig. 2). This is preventable if less irrigation is used so as to avoid breaching field capacity: note, however, that there is probably no mitigation to be gained by using lower irrigation application rates, as rates were already $<4 \mathrm{~mm} / \mathrm{h}$.

If minimising irrigation runoff fails, emphasis then falls on strategies to either mitigate the effect of animals while grazing winter forage crops or altering soil conditions to decrease potential loss. Two strategies are being trialled at the North Otago site. These are: restricted grazing of the winter forage crop (allowing animals to get maintenance feed by grazing for only $3-4 \mathrm{~h}$ ) and the application of aluminium sulphate. Results are not presented in this paper due to insufficient data. However, restricted grazing has previously been shown to decrease $\mathrm{P}$, E. coli (a faecal indicator bacterium) and SS losses from cattle grazed winter forage plots (McDowell et al. 2005). It will be interesting to see if this translates to sheep. Aluminium sulphate has been used to increase the sorption capacity of soils and decrease P losses (largely as dissolved P) from cropped and pasture fields in the US after manure application (Smith et al. 2001). Our strategy is to spray $40 \mathrm{~kg} \mathrm{Al} / \mathrm{ha}$ a couple of days after the winter grazing of plots to improve $\mathrm{P}$ sorption capacity of the Pallic soils, which tend to have low P retention (e.g. $15-20 \%)$. This application is also likely to decrease $\mathrm{P}$ solubility in dung.

\section{Conclusions}

The P losses from forage crop plots grazed in winter in North Otago are comparable to annual catchment losses for dairy grazed pastures in other parts of the country. Overland flow was the main mechanism for P and sediment loss. Phosphorus losses from the cattle grazed crop plots were approximately double that of the sheep grazed plots and seven times that of the sheep grazed pasture. Phosphorus losses in sub-surface flow made up about $6 \%$ of total (overland and sub-surface) losses. Approximately $30 \%$ of $\mathrm{P}$ losses were associated with irrigation events. Nitrate- $\mathrm{N}$ losses under the urine patch were greater from a cattle grazing scenario than for sheep. The leaching of residual mineral $\mathrm{N}$ under fallow conditions was significantly less than for urine application losses. Therefore, it appears that animals are the predominant driver of $\mathrm{NO}_{3}^{-}-\mathrm{N}$ losses from grazed winter forage crops. In addition to minimising overland flow via irrigation, potential mitigation options such as aluminium sulphate, restricted grazing and the nitrification inhibitor, DCD are being assessed to further decrease nutrient loss from winter grazed forage crops

\section{ACKNOWLEDGEMENTS}

This research was funded by the New Zealand Fertilizer Manufacturer's Research Association and the New Zealand Foundation for Research, Science and 
Technology (contracts C02x0304, C10X0320, AGRX002 and C10X0017). The technical assistance of Sonya Walker, Jim Paton, Ben Lumsden, Dennis Enright, Jane Campbell, MS Srinivasan, and Kim Walker, is gratefully acknowledged.

\section{REFERENCES}

Bilotta, G.S.; Brazier, R.E.; Haygarth, P.M. 2007. The impacts of grazing animals on the quality of soils, vegetation, and surface waters in intensively managed grasslands. Advances in Agronomy 94: 237-280.

de Klein, C.A.M.; Barton, L; Sherlock R.R.; Li, Z.; Littlejohn, R.P. 2003. Estimating a nitrous oxide emission factor for animal urine from some New Zealand pastoral soils. Australian Journal of Soil Research 41: 381-399.

Drewry, J.J.; Littlejohn, R.P.; Paton, R.J. 2000. A survey of soil physical properties on sheep and dairy farms in southern New Zealand. New Zealand Journal of Agricultural Research 43: 251-258.

Drewry, J.J.; Paton, R.J. 2005. Soil physical quality under cattle grazing of a winter fed brassica crop. Australian Journal of Soil Research 43: 525-531.

Haynes, R.J.; Williams, P.H. 1993. Nutrient cycling and soil fertility in the grazed pasture ecosystem. Advances in Agronomy 49: 119-199.

Hewitt, A.E. 1998. New Zealand Soil Classification. Manaaki Whenua Press, Lincoln, NZ, 133 pp.

Houlbrooke, D.J.; Morton, J.D.; Paton, R.J.; Littlejohn, R.P. 2006. The impact of land-use intensification on soil physical quality and plant yield response in the North Otago Rolling Downlands. Proceedings of the New Zealand Grassland Association 68: 165-172.

Leytem, A.B.; Mikkelsen, R.L.; Gilliam, J.W. 2002. Sorption of organic phosphorus compounds in Atlantic Coastal Plain soils. Soil Science 167: 652658.

McDowell, R.W. 2006a. Phosphorus and sediment loss in a catchment with winter forage crop grazing by dairy cattle. Journal of Environmental Quality 35: 575583.

McDowell, R.W.2006b. Contaminant losses in overland flow from cattle, deer and sheep dung. Water, Air and Soil Pollution 174: 211-222.

McDowell, R.W.; Sharpley, A.N. 2001. Phosphorus losses in subsurface flow before and after manure application to intensively farmed land. The Science of the Total Environment 278: 113-125.

McDowell, R.W.; Monaghan, R.M. 2002. The potential for phosphorus loss in relation to nitrogen fertiliser application and cultivation. New Zealand Journal of Agricultural Research 45: 245-253.

McDowell, R.W.; Larnard, S. 2008. Surface water quality and nutrients: what should the focus be? In press. In: Implementing carbon and nutrient management in agriculture. Ed. Curie, L.D, Occasional report No 21. Fertiliser and Lime Research Centre, Massey University, Palmerston North, New Zealand McDowell, R.W.; Drewry, J.J.; Paton, R.J.; Carey, P.L.; Monaghan, R.M.; Condron, L.M. 2003. Influence of soil treading on sediment and phosphorus losses in overland flow. Australian Journal of Soil Research 41: 949-961.

McDowell, R.W.; Biggs, B.J.F.; Sharpley, A.N.; Nguyen, L. 2004. Connecting phosphorus loss from agricultural landscapes to surface water quality. Chemistry and Ecology 20: 1-40.

McDowell, R.W.; Drewry, J.J.: Muirhead, R.W.; Paton, R.J. 2005. Restricting the grazing time of cattle to decrease phosphorus, sediment and E. coli losses in overland low from cropland. Australian Journal of Soil Research 43: 61.

Monaghan, R.M.; Wilcock, R.J.; Smith, L.C.; Tikkisetty, B.; Thorrold, B.S.; Costall, D. 2007. Linkages between land management activities and water quality in an intensively farmed catchment in southern New Zealand. Agriculture, Ecosystems and Environment 118: 211-222.

Nash, D.M.; Halliwell, D.J. 1999. Fertilisers and phosphorus loss from productive grazing systems. Australian Journal of Soil Research 37: 403-429.

Nash, D.M.; Halliwell, D.; Cox, J. 2002. Hydrological mobilization of pollutants at the field/slope scale. pp. 225-242. In: Agriculture, Hydrology and Water Quality. Eds. Haygarth, P.M.; Jarvis, S.C. CABI International, Oxon, UK.

Nguyen, M.L.; Sheath, G.W.; Smith, C.M.; Cooper, A.B. 1998. Impact of cattle treading on hill land 2. Soil physical properties and contaminant runoff. New Zealand Journal of Agricultural Research 41: 279290.

Smith, L.C.; Monaghan, R.M.; Ledgard, S.F.; Catto, W.D. 2005. The effectiveness of different nitrification inhibitor formulations in limiting nitrate accumulation in a Southland pastoral soil. New Zealand Journal of Agricultural Research 48: 517-529.

Smith, D.R.; Moore, P.A. Jr.; Griffis, C.L.; Daniel, T.C.; Edwards, D.R.; Boothe, D.L. 2001. Effects of alum and aluminium chloride on phosphorus runoff from swine manure. Journal of Environmental Quality 30: 992-998.

Thomas, D.; Heckrath, G.; Brookes, P.C. 1997. Evidence of phosphorus movement from Broadbalk soils by preferential flow. pp. 369-370. In: phosphorus loss from soil to water. Eds. Tunney, H.; Carton, O.T.; Brookes, P.C.; Johnston, A.E. CABI International, Oxon, UK.

Watanabe, F.S.; Olsen, S.R. 1965. Test of an ascorbic 
acid method for determining phosphorus in water and $\mathrm{NaHCO} 3$ extracts from soil. Soil Science Society of America Proceedings 29: 677-678.

Wilcock, R.J.; Monaghan, R.M.; Thorrold, B.S.;
Meredith, A.S.; Betteridge, K.; Duncan, M.J. 2007. Land-water interactions in five contrasting dairying catchments: issues and solutions. Land Use and Water Resources Research 7: 2.1-2.10. 